\title{
Bioactivity-guided evaluation of the root extract of Plumbago zeylanica
}

\author{
Modupe Monsurat RAIMI ${ }^{2}$ and Oluboade Oluokun OYEDAPO ${ }^{1 *}$ \\ ${ }^{I}$ Department of Biochemistry, Faculty of Science, Obafemi Awolowo University, Ile-Ife, Nigeria. \\ ${ }^{2}$ Department of Applied Sciences, Faculty of Science, Osun State Polythenic, Iree, Nigeria. \\ Corresponding author, E-mail: ooyedapo@yahoo.co.uk
}

\begin{abstract}
The haemagglutination, free radical scavenging and membrane stabilizing activities of combined ethyl acetate/diethylether extract of root of Plumbago zeylanica were investigated. The combined fraction (ethyl acetate/diethylether) was chromatographed on silica gel column using hexane/ethyl acetate gradient elution $(100: 0-0: 100 \mathrm{v} / \mathrm{v})$ to afford seven fractions $(\mathrm{A}-\mathrm{F})$ based on $\mathrm{R}_{\mathrm{f}}$ values and phytochemical evaluation tests. The fractions were assayed for phytochemical constituents, total phenol contents, free radical scavenging and membrane stabilizing activities and toxicity using haemaglutination assay method. The phytoconstituents include anthraquinones, flavonoids and phenolic acids. The phenolic contents in the fractions ranged between $0.27 \pm 0.04$ and $0.93 \pm 0.28 \mathrm{mg} / \mathrm{g}$ tannic acid equivalent (TAE). The fractions exhibited strong and appreciable free radical scavenging and membrane stabilizing activities and agglutinated red blood cells, which implied toxicity. These activities compared favourably with standard anti-inflammatory and anti-oxidant drugs. The results revealed that while some of the fractions haemaglutinated red blood cells, others provided effective antioxidant and anti-inflammatory activities.

() 2009 International Formulae Group. All rights reserved.
\end{abstract}

Keywords: Haemagglutination, free radical scavenging activity, membrane stabilizing activity, flavonoids.

\section{INTRODUCTION}

Plumbago zeylanica (Linn) belongs to the Plumbaginaeceae family. It is employed in folk medicine as remedies for treating scabies and ulcers, fever, intestinal parasites, external and internal trauma and rheumatic pain (Dalziel 1959; Chiu and Chang, 1986; Li, 1998; Simonsen et al., 2001; Lin et al., 2003; Dai et al., 2004;). It is also employed in the treatment of contusion of the extremities, dysmenorrhea and elimination of intestinal parasites (Amin and Mousa, 2007). Its phytochemical constituents include flavonoids, naphthoquinones, binaphthoquinones, coumarins, $\beta$-sitosterol, saponins, cardiac glycosides, tannins, alkaloids, and cytotoxic plumbagic acid glucosides (Sankaram et al., 1976; Gunaherath et al., 1983; Gunaherath and Gunatikka, 1988;
Oyedapo 1996; Gupta et al., 1999; Beg and Ahmad, 2000; Lin et al., 2003; Ahmad and Aqil, 2006; Olagunju et al., 2006). Earlier studies (Oyedapo and Amos, 1997; Oyedapo et al., 2004) revealed that the ethanolic and aqueous fraction of root extract of Plumbago zeylanica have been demonstrated to be nontoxic while ethyl acetate fraction was extremely toxic to experimental rats. Owing to the observed toxic nature of ethyl acetate and diethylether extracts of root of $P$. zeylanica, this study was designed to investigate the chemical nature and activities of the combined extracts. Therefore, this paper reports the fractionation of the combined ethyl acetate/ diethylether fraction of the root extract of Plumbago zeylanica and the evaluation of the fractions for toxicity by haemagglutination 
technique as well their free radical scavenging and membrane stabilizing activities.

\section{MATERIALS AND METHODS Plant materials}

Roots of Plumbago zeylanica were collected between July 2005 and October 2006 from Ajebandele Village, Ile- Ife, Nigeria. The plants had been identified and authenticated by Dr. A. A. Jaiyeola, formerly of Department of Botany, Obafemi Awolowo University, Ile- Ife, Nigeria and presently of Department of Botany and Microbiology, University of Ibadan, Ibadan, Nigeria. The Herbarium specimen number was OC148 FE. The roots were washed, cut into tiny bits and air-dried in the laboratory over a period of 30 days.

\section{Reagents and chemicals}

Potassium dihydrogen orthophosphate, sodium dihydrogen orthophosphate, sodium carbonate, trisodium citrate, sodium chloride and sodium azide were products of British Drug House Chemicals Limited, Poole, England. Ethanol, diethylether and ethyl acetate were products of Sigma Aldrich, Germany. Silica gel was from May and Baker Limited, England.

All reagents were of analytical grade and solutions were made with glass distilled water.

\section{Spectroscopic readings}

The absorbance readings were recorded on CamSpec M201 Vis-Spectrophotometer Model (Cambridge CB2 4BG) and Pharmacia Biotech Novaspec II Spectrophotometer (Pharmacia Chemical Limited, Uppsala Sweden)

\section{Preparation and fractionation of root extract of $P$. zeylanica}

Air dried powdered root $(3 \mathrm{~kg})$ of $P$. zeylanica was successively extracted with diethylether, ethyl acetate and the residue was finally suspended in $80 \%(\mathrm{v} / \mathrm{v})$ ethanol. The ethanolic extract was partitioned successively with diethylether followed by ethyl acetate according to a procedure that was based on procedures described by Adeoye and Oyedapo (2004) and Ikekawa and Suzuki (1981).The diethylether and ethyl acetate extracts were combined followed by evaporation to dryness under reduced pressure at $30{ }^{\circ} \mathrm{C}$. The residue was fractionated on silica gel column using hexane/ethyl acetate solvent mixtures gradient elution 100:0\% - 0:100\%.

Fractions $(10 \mathrm{ml})$ were collected at a flow rate of $1 \mathrm{ml} / \mathrm{min}$. A total of 620 fractions were collected and pooled into thirteen fractions labelled F1 - F13 based on their $R_{f}$ values. All these operations were carried out at room temperature. Each pooled fraction was evaporated to dryness under reduced pressure at $30{ }^{\circ} \mathrm{C}$ and kept for further analyses.

\section{Thin layer chromatography}

Various fractions were chromatographed on precoated silica gel $\mathrm{F}_{254}$ plates in chloroform: acetone: propan-2-ol (85: 15: 20 $\mathrm{v} / \mathrm{v} / \mathrm{v})$ and toluene- ethyl acetate - $90 \%$ formic acid (5: 4: $1 \mathrm{v} / \mathrm{v} / \mathrm{v})$ with spray reagent, $1 \%$ (w/v) $\mathrm{CeSO}_{4}$ in $6 \mathrm{~N} \mathrm{H}_{2} \mathrm{SO}_{4}$ and $1 \%$ (w/v) $\rho$ dimethylamino-benzaldehyde in $96 \%(\mathrm{v} / \mathrm{v})$ ethanol. The plates were air dried, sprayed and placed in the oven at $105{ }^{\circ} \mathrm{C}$ for $5 \mathrm{~min}$. The plates were examined before and after chemical treatment followed by examination for brown, pink, purple and blue-green spots. The $R_{f}$ values were calculated and the reactions to specific reagents noted.

\section{Phytochemical tests}

The fractions were tested for the presence of anthraquinones and flavonoids as described by Trease and Evans (2002) and alkaloids, saponins, tannins as described by Sofowora (1993). The fractions were then pooled as follows: A (F1 - F5), B (F6), C (F7 F9), D (F10), E (F11), F (F12) and G (F13). The pooling of fractions was based on the $R_{f}$ values and positive reactions to specific chemical reagents.

\section{Biochemical analyses \\ Haemagglutination assay}

Haemagglutination assay was carried out as described by Carmichael and Bent (1981) in U-shaped microtitre plate with fixed human red blood cells. The human red blood cells were fixed with formaldehyde based on procedures earlier described by Butler (1963).

Aliquots $(0.1 \mathrm{ml})$ of $4 \% \quad(\mathrm{v} / \mathrm{v})$ formaldehyde fixed red blood cells were 
added to all the wells. The microtiter plate was covered and incubated at room temperature in order to allow for agglutination of erythrocytes to take place. The titer was taken as the reciprocal of the last dilution showing agglutination of red blood cells.

\section{Estimation of total phenol content}

The total phenol concentration of the fractions was estimated using FolinCiocalteus reaction method according to the procedure described by Singleton et al. (1999) with tannic acid as standard. The total assay volume was $3.75 \mathrm{ml}$. The standard consisted of $0.75 \mathrm{ml}$ of Folin's reagent, $1.0 \mathrm{ml}$ of $15 \%$ (w/v) Sodium carbonate solution, varying volumes of $250 \mu \mathrm{g}$ tannic acid solution and distilled water. The test consisted of $0.25 \mathrm{ml}$ of each fraction, $0.75 \mathrm{ml}$ Folin's reagent and $1.0 \mathrm{ml}$ of $15 \%(\mathrm{w} / \mathrm{v})$ Sodium carbonate solution and $1.75 \mathrm{ml}$ distilled water. The contents of all tubes were mixed thoroughly, incubated at room temperature for at least 10 min. The absorbance was read at $765 \mathrm{~nm}$ against reagent blank.

Assay of free radical scavenging activity

Evaluation of the free radical scavenging activities of the fractions was by 2,2-diphenyl-1-picryl-hydrazylhydrate

(DPPH) - free radical scavenging assay based on procedures earlier described by Blois (1958) as reported by Cakir et al. (2003) with slight modifications and ascorbic acid as the standard. Solutions of the fractions were prepared in ethanol, and ascorbic acid solution $(2.5 \mathrm{mg} / \mathrm{ml})$ was prepared in distilled water. The sample (fraction/ ascorbic acid) reaction mixtures consisted of $1 \mathrm{ml}$ of $0.2 \mathrm{mM} \mathrm{DPPH}$, varying volumes of sample (volumes of fraction/ ascorbic acid solution) were pipetted such that the concentration of the fraction solution per total assay volume was 0,50 , $100,150,200,250,300,400,500$ and 600 $\mu \mathrm{g} / \mathrm{ml}$ ) and the volume was made up to $3 \mathrm{ml}$ with $10 \mathrm{mM}$ acetate buffer, $\mathrm{pH}$ 5.5. The control reaction mixture consisted of $2.0 \mathrm{ml}$ of $10 \mathrm{mM}$ acetate buffer; and $1.0 \mathrm{ml}$ of $0.2 \mathrm{mM}$ DPPH. The reaction mixtures were well shaken and incubated at room temperature in the dark for $30 \mathrm{~min}$. The absorbance was read at $517 \mathrm{~nm}$ against reagent blank.

The percentage DPPH free radical scavenging activity was estimated using the expression:
Absorbance of control - Absorbance of sample $X 100$

\section{Absorbance of control}

$\mathrm{EC}_{50}$ values of fractions/ ascorbic acid were calculated by linear regression of plots where the abscissa represented the concentration of fractions/ ascorbic acid and the ordinate the average percentage of DPPH free radical scavenging activity from three separate assays.

\section{Assay of membrane stabilizing activity}

The membrane stabilizing activity assay was carried out as earlier described by Sadique et al. (1989) and Oyedapo et al. (2004) using 2\% v/v bovine erythrocyte suspension and indomethacin as the standard anti-inflammatory drug. The assay mixture consisted of hyposaline $(2.0 \mathrm{ml}), 0.15 \mathrm{M}$ sodium phosphate buffer at $\mathrm{pH} 7.4(1.0 \mathrm{ml})$, varying volumes of drug (fraction or Indomethacin) $(0.0-1.0 \mathrm{ml}), 2 \%(\mathrm{v} / \mathrm{v})$ erythrocyte suspension in isosaline $(0.5 \mathrm{ml})$ and varying volumes of isosaline to give a total assay volume of $4.5 \mathrm{ml}$.

The control $(4.5 \mathrm{ml})$ was prepared as above except the drugs were omitted while drug control $(4.5 \mathrm{ml})$ lacked erythrocyte suspension. The reaction mixtures were incubated at $56^{\circ} \mathrm{C}$ for $30 \mathrm{~min}$. The tubes were cooled under running water followed by centrifugation at $3000 \mathrm{rpm}$ on Bench Centrifuge Model 800D (Microfield Instrument, England), for $10 \mathrm{~min}$ at room temperature. The supernatants were collected followed by reading the absorbance of the released haemoglobin at $560 \mathrm{~nm}$. Then, the percentage membrane stability was estimated from the following expression:

\section{$\underline{100-(\text { Drug test value- Drug control value) }} \times 100$}

Control value

The control represents $100 \%$ lysis.

\section{Statistical analysis}

The data were expressed as the mean \pm sem of three consistent readings. The significance of the differences between controls, drugs and fractions were analyzed by the Student's t-test and analysis of variance (ANOVA). Values of $\mathrm{P} \leq 0.05$ were considered to be statistically significant. 


\section{RESULTS}

The yield of the combined fraction was $10.11 \mathrm{~g}$ representing $0.33 \%$ of the starting material. The phytochemical analyses revealed the presence of flavonoids, anthraquinones and phenolic acids as a result of positive reactions produced by these molecules.

Moreover, Fractions B, C, D, E and G agglutinated fixed bovine erythrocytes at concentrations of $9.0 \mathrm{mg} / \mathrm{ml}, 5.0 \mathrm{mg} / \mathrm{ml}, 3.75$ $\mathrm{mg} / \mathrm{ml}, \quad 7.75 \quad \mathrm{mg} / \mathrm{ml}$ and $29.5 \mathrm{mg} / \mathrm{ml}$ respectively. Phosphate buffered solution of fraction $\mathrm{G}$ agglutinated the bovine red blood cells to a titre of $2^{3}$ which was equivalent to $74 \mu \mathrm{g} / \mathrm{ml}$.

The phenolic concentrations were expressed as tannic acid equivalent $(\mathrm{mg} / \mathrm{g}$ TAE), with fraction $\mathrm{A}$ having the highest phenol content and fractions B and D the least values. The mean values obtained for various fractions were A $(9.30 \pm 0.28)$; $\mathrm{B}(0.25 \pm 0.06)$; $\mathrm{C}(0.37 \pm 0.10)$; $\mathrm{D}(0.27 \pm .04) ; \mathrm{E}(0.92 \pm 0.06)$; $\mathrm{F}(5.17 \pm 0.08)$ and $\mathrm{G}(8.88 \pm 0.10)$.

Only fractions $\mathrm{C}, \mathrm{D}, \mathrm{F}$ and $\mathrm{G}$ exhibited DPPH free radical scavenging activities. The $\mathrm{EC}_{50}$ values of fractions $\mathrm{C}, \mathrm{D}$ and $\mathrm{G}$ were calculated to $216.99 \pm 3.52 \mu \mathrm{g} / \mathrm{ml}, 283.40 \pm$ $5.17 \mu \mathrm{g} / \mathrm{ml}$ and $182.81 \pm 2.46 \mu \mathrm{g} / \mathrm{ml}$ respectively while those of Fraction $\mathrm{F}$ and ascorbic acid exhibited higher activity (Figure $1)$.

The mean maximum membrane stabilizing activities of various fractions and mode of protection were A, $60.35 \pm 0.48 \%$ (biphasic); B, 39.93 $\pm 2.13 \%$ (monophasic); D, $37.29 \pm 0.69$ (biphasic); F, $63.00 \pm 6.84 \%$ (monophasic); G, $50.22 \pm 9.06 \%$ (biphasic) and Indomethacin, 59.74 $\pm 5.07 \%$ (monphasic) respectively (Figure 2). $\mathrm{EC}_{50}$ values obtained from regression lines analyses showed a good coefficient of determination $\left(r^{2} \geq 0.875\right)$.

\section{DISCUSSION}

The popularity of complementary medicine has increased considerably. Presently, no available statistics on the survey of the use of herbal medicine has indicated that large percentage of the population suffering from various form of ailments employ at least one form of unconventional therapy including herbal medicine ( Eisenberg et al., 1993; Maclennan et al., 1996; Basu and
Hazraa, 2006). Even, the World Health Organization (WHO, 1984) has suggested the evaluation of the potential of plant materials as effective therapeutic agents in the areas in which there are shortages of safe modern drugs or in cases of where orthodox drugs exhibit various side effects (Upadhayay and Pandey, 1984).

The root of Plumbago zeylanica and its constituents are credited with potential therapeutic properties including atherogenic, cardiotonic, hepatoprotective, antioxidant and neuroprotective properties (Tilak et al., 2004; Alpana 1996). Moreover, literature surveys revealed that leaf and root extracts of $P$. zeylanica exhibited anti-inflammatory, antimicrobial, antimalarial as well as antifungal activities (Thomas, 1989; Oyedapo et al., 1999). This paper reports the haemagglutination, DPPH-free radical scavenging and bovine erythrocyte stabilization activities of ethyl acetate fraction of root of $P$. zeylanica.

Phytochemical analyses of ethyl acetate fraction of $P$. zeylanica revealed that the chemical composition included phenolics, anthraquinones and flavonoids as a result of positive reactions for the presence of these molecules. The activities observed in this investigation could be attributed mainly to these biomolecules. It has been speculated that remarkable anti-inflammatory activities of plants are attributed to their sterol and flavonoid contents (Ahmad et al., 1993; Beg and Ahmad, 2000). Flavonoids and related phenols are ubiquitous in land plants and they exhibit arrays of biological activities which include free radical scavenging, antiinflammatory activity, inhibition of cell proliferation, promotion of differentiation, and function as anti-oxidant and are mediators of tyrosine kinases (Ulubelen 1980; Kuo 1996; Mabry and Yu et al., 2005).

Experimentally and pharmacologically a good relationship has been established between brine shrimp lethality and haemaglutination of erythrocyte in the screening, detection and quantification of toxic compounds (Meyer et al., 1982; Mackeen et al., 2000). The toxicity evaluation of the fractions in the present study was by hemagglutination assay. The agglutination 


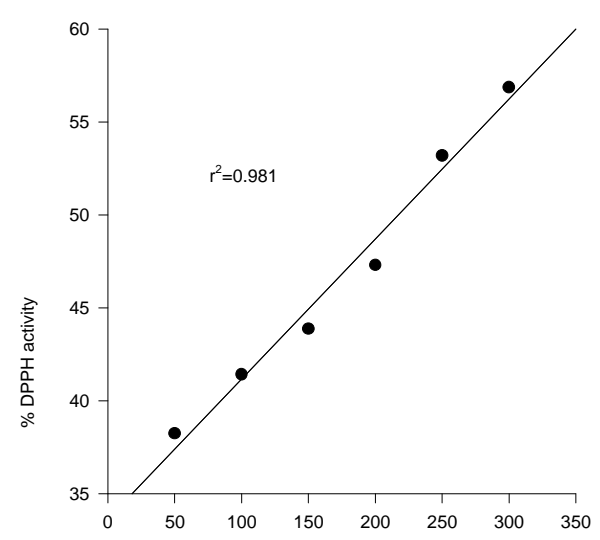

Concentration $(\mu \mathrm{g} / \mathrm{ml})$ (a)Fraction $\mathbf{C}$

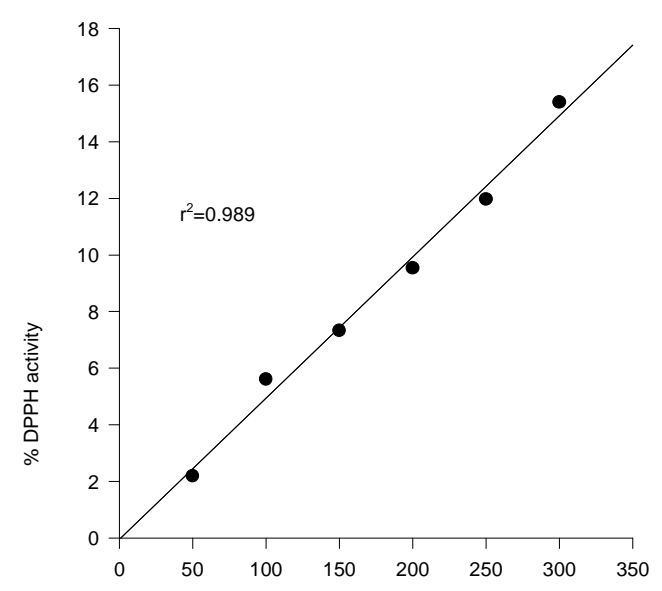

Concentration $(\mu \mathrm{g} / \mathrm{ml})$

(c) Fraction $\mathbf{F}$

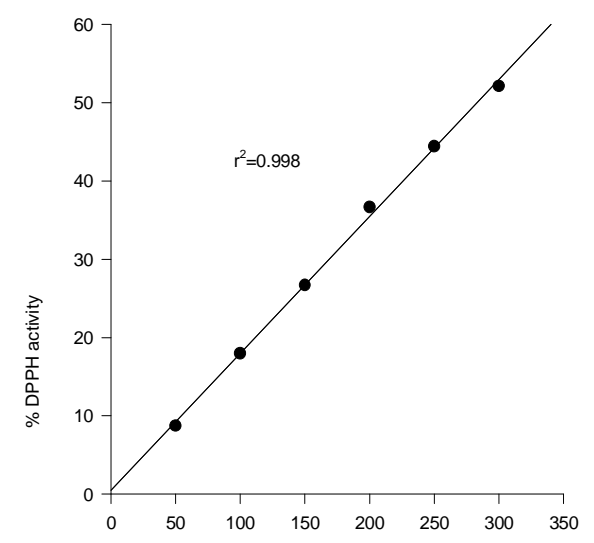

Concentration $(\mu \mathrm{g} / \mathrm{ml})$

(b) Fraction D

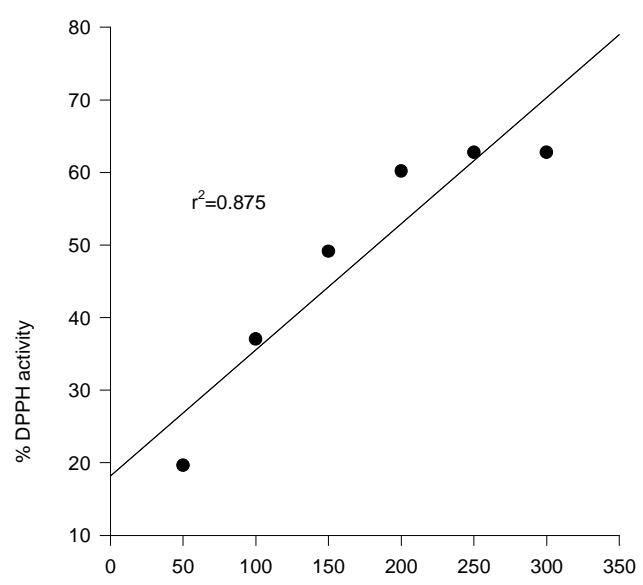

Concentration $(\mu \mathrm{g} / \mathrm{ml})$

(d) Fraction $\mathbf{G}$

Figure 1: Linear regression of plots of DPPH-free radical scavenging activity versus concentration of fractions.

of red blood cell is always attributed to the presence of toxic factors and taken as positive response just like other lethality tests. Investigators have employed haemaglutination technique for the evaluation of type $\mathrm{c}$ toxins of freshwater cyanobacteria (blue green algae), Microcystis aerugimosa, Anabaena flos-aquae anatoxin-c and various extracts of Pentaclethra macrophylla (Carmichael and Bent, 1981; Frisvad and Filtenborg, 1983; Okorie et al., 2006). Therefore, erythrocyte agglutination was employed for the detection and quantification of toxicity of fractions in this investigation. Fraction $G$ gave positive responses when dissolved both in organic solvent and phosphate buffered saline solution (PBS). Fractions B, C, D and E gave positive response when dissolved in organic solvent but negative response when dissolved in PBS solution. Therefore toxic constituents of nonpolar fraction of root of $P$. zeylanica are contained in fractions B, C, D, E and G. 


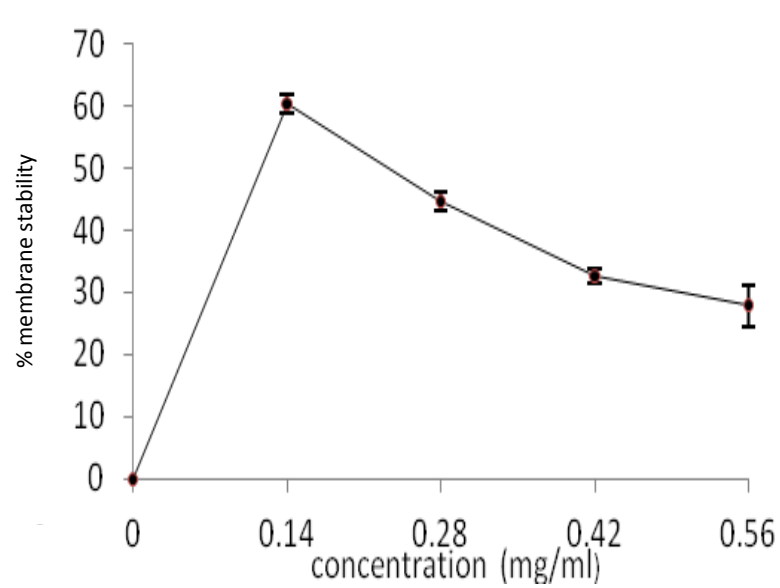

(a): Fraction A

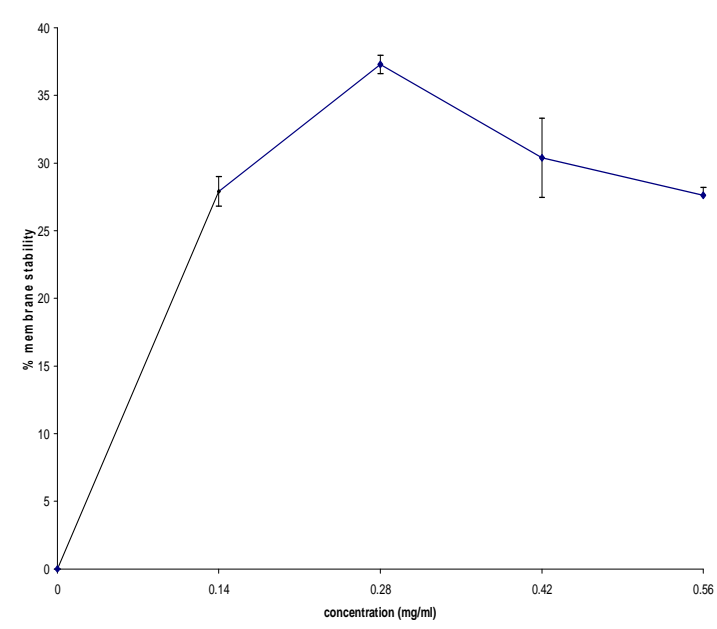

(c): Fraction D

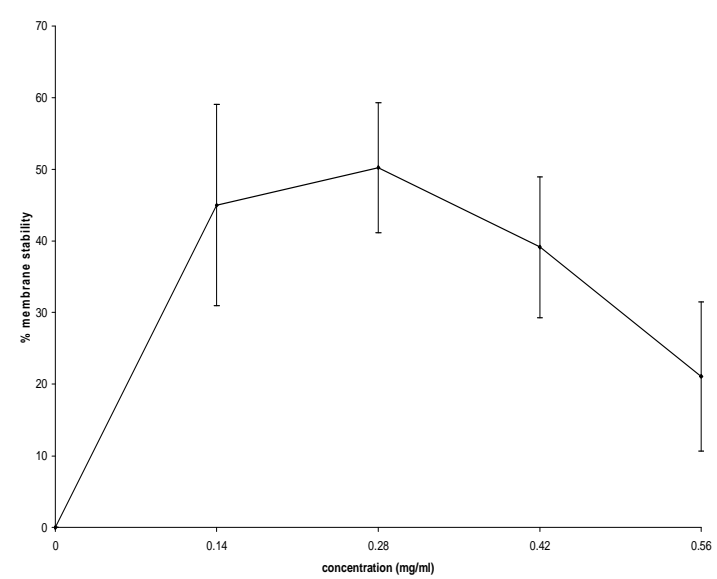

(e): Fraction G

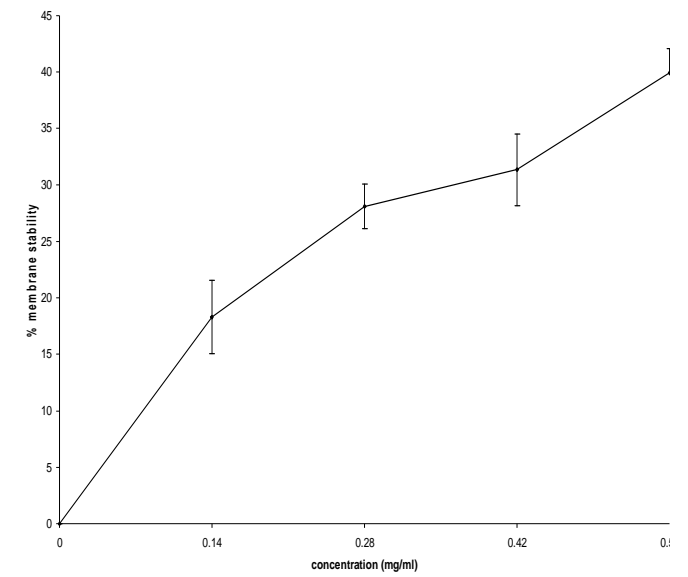

(b): Fraction B

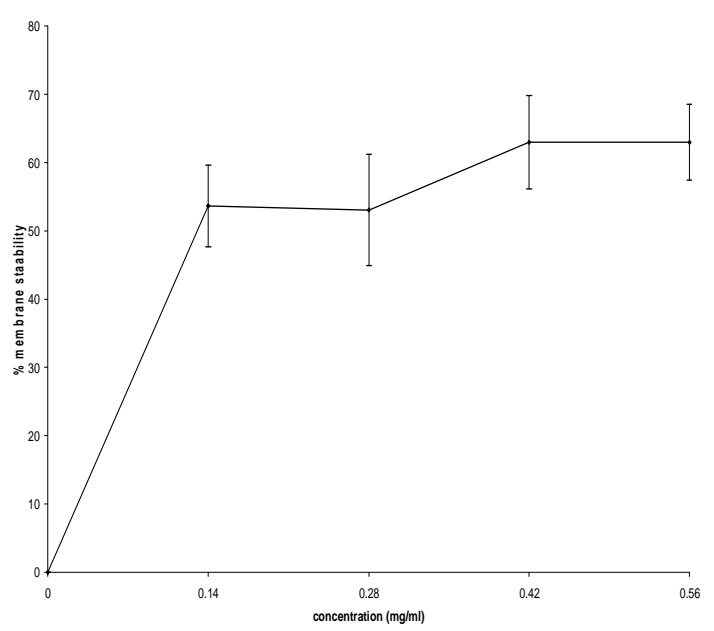

(d): Fraction F

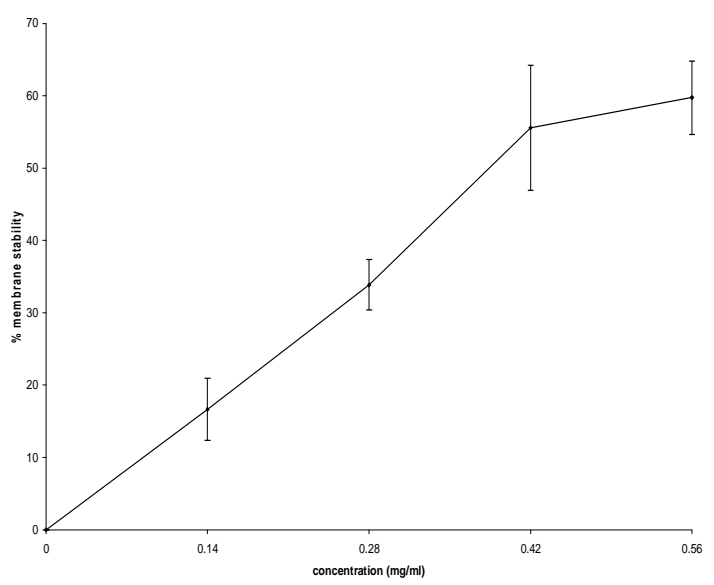

(f): Indomethacin

Figure 2: Bovine red blood cell membrane stabilizing profiles of various fractions of extract of Plumbago zeylanica. The assay was performed as described in the text. Each value represents the Mean \pm SEM of three consistent readings. 
2,2-diphenyl-1-picryl-hydrazyl-hydrate (DPPH) is a free radical stable at room temperature and produces a violet solution in ethanol. DPPH is reduced in the presence of an antioxidant molecule giving rise to uncoloured ethanol solution (Mensor et al., 2001). DPPH stable free radical method is an easy, rapid and sensitive way to assay the antioxidant activity of a specific compound or plant extracts (Pourmorad et al., 2006). The results of DPPH radical scavenging assay showed that fractions $\mathrm{C}, \mathrm{D}$ and $\mathrm{G}$ exhibited DPPH-free radical scavenging activities at varying concentrations. These results agreed with earlier investigations (Mensor et al., 2001) where general correlation was observed between antioxidant activity (free radical scavenging activity) and the phenolic content. The mechanisms of action of flavonoids might have been exerted through scavenging activity (Amin and Mousa, 2007) thus; the presence of flavonoids in fractions C, D, E, F and G could be responsible for the observed activity.

The ability of extracts or compounds to stabilize red blood cells subjected to both heat and hypotonic induced lyses have been attributed to the anti-inflammatory activity of such extract or compound in earlier investigations (Sadique et al., 1989; Oyedapo 1996; Oyedapo et al., 1997; 2004; Falade et al., 2005). Flavonoids have been demonstrated to exert profound anti-inflammatory activities (Pourmorad et al., 2006) by exhibiting stabilizing effect on lysosomes both in vivo and in vitro in experimental animals (VanCargegham, 1972; Sadique et al., 1989; Middleton, 1996). The exhibition of remarkable membrane stabilizing activities by fractions $\mathrm{A}, \mathrm{F}$ and $\mathrm{G}$ could be attributed to the presence of phenolics as these fractions gave positive reactions for their presence. Studies have shown that compounds that exhibit membrane stabilizing activities are known to interfere with early phase of inflammatory reactions that is, prevention of the release of phospholipases that initiate the formation of inflammatory disorders (Aitadafoun et al., 1996; Neergheen et al., 2006; Umukoro and Ashorobi, 2006). The membrane stabilizing profiles of various fractions revealed that the fractions protected the bovine erythrocytes exposed to both heat and hypotonic induced lyses to varying degrees (Figure 2). Moreover, the results revealed that the activity of the fractions compared favourably with that of a non-steroidal anti-inflammatory drug (NSAD) indomethacin, with Fraction A exerting highest membrane stability properly and followed by fraction $F$ while fraction $D$ gave the least protection. Thus, the exhibition of membrane stabilizing activities by fractions $D, F$ and $G$ may probably be due to the presence of flavonoid in these fractions.

The results revealed that the toxic constituents of root extract of $P$. zeylanica were contained in fractions B, C, D, E and G. These compounds were mainly extractable with ethyl acetate and contained phenolic acids, anthraquinones and flavonoids.

\section{ACKNOWLEDGEMENTS}

The authors expressed their profound gratitude to $\mathrm{Dr}$ (Mrs) R. A. Togun, Department of Haematology and Immunology, Faculty of Basic Medical Sciences, Obafemi Awolowo University, IleIfe, Nigeria for her assistance in the haemaglutination assays of the fractions.

\section{REFERENCES}

Adeoye BA, Oyedapo OO. 2004. Toxicity of Erythrophleum guineense stem bark: role of alkaloidal fraction. African $J$. Traditional Complementary and Alternative Medicines, 1: 45-54.

Ahmad I, Aqil F. 2006. In vitro Efficacy of Bioactive Extracts of 15 Medicinal Plants against Es-beta L -producing multi-drug Resistant Enteric Bacteria. Microbiology Res., 162(3): 264 - 275.

Aitadafoun M, Mounieri C, Hayman SF, Binistic C, Bon C, Godhead J. 1996. 4Alkobenzamides as new potent phospholipases A2 inhibitors. Biochemical Pharmacology, 51: 737-742.

Amin A, Mousa M. 2007. Merits of AntiCancer Plants from the Arabian Gulf Region. Cancer Therapy, 5: 55-66.

Beg AZ, Ahmad I. 2000. Effect of Plumbago zeylanica extract and certain curing agents on multidrug Resistant Bacteria of Clinical Origin. World J. Microbiol. and Biotechnol., 16: 841-844.

Butler WT. 1963. Haemagglutination studies with formalinised erythrocytes. $J$. Immunology, 90: 663-671. 
Carmichael WW, Bent PE. 1981. Haemagglutination method for detection of freshwater cyanobacter (blue-green algae) toxins. Applied and Environmental Microbiol., 41(6): 1383 - 1388.

Cakir A, Mavi A, Yildin A, Duru ME, Harmander M, Kaazaz C. 2003. Isolation and characterization of antioxidant phenolic compounds from the aerial parts of Hypericum hyssopifolium L. by activity guided fractionation. J. Ethnopharmacol., 87: 73-83.

Chiu NY, Chang KH. 1986. The illustrated Medicinal Plants of Taiwan (Vol. 3). SMC Publishing Inc.: Taipei, Taiwan; 118.

Dai Y, Hou L, Chan Y, Cheng L, But PP. 2004. Inhibition of immediate allergic reactions by ethanol extracts from Plumbago zeylanica stems. Biological and Pharmaceutical Bulletin, 27(3): 429 432.

Dalziel JM. 1959. The Useful Plants of West Tropical Africa: an Appendix to the Flora of West Tropical Africa. Crown Agents for Overseas Government and Administration: Millbank London, S.W.I.; 424426.

Frisvad JC, Filtenborg O. 1983. Classification of terverticillate penicillia based on profiles of mycotoxins and other secondary metabolites. Applied and Environmental Microbiology, 46(6): 1301-1310.

Gunaherath GMKB, Gunatilaka AAL, Sultanbawa MUS, Slasubramaniam S. 1983. 1,2(3)-Tetrahydro-3,3'-biplumbagin: A naphthalene and other constituents from Plumbago zeylanica. Phytochemistry, 22: 1245-1247.

Gunaherath GMKB, Gunatilaka AAL. 1988. Studies on Medicinal and Related Plants of Sri Lanka. Part 18. Structure of a New Naphthoquinone from Plumbago zeylanica. J. Chemical Society, 1: 407410.

Gupta A, Gupta A, Singh J. 1999. New naphthoquinone from Plumbago zeylanica. Pharmaceutical Biology, 37(4): 321-323.

Ikekawa N, Suzuki M. 1981. Extraction and isolation of biologically active compounds. In Advances in Natural
Products Chemistry. A. Halsted Press: Book Kodensha Limited; 489-502.

Kuo SM. 1996. Antiproliferative potency of structurally distinct dietary flavonoids on human colon cancer cells. Cancer Letters, 110: $41-48$.

Lin LC, Yang LL, Chou CJ. 2003. Cytotoxic naphtoquinones and plumbagic acid glucosides from Plumbago zeylanica. Phytochemistry, 62: $619-622$.

Mabry TJ, Ulubelen A. 1980. Chemistry and utilization of phenylpropanoids including flavonoids, coumarins and ligans. $J$. Agric. Food Chemistry, 28: 188-196.

Mackeen MM, Ali AM, Laps NH, Kawazu K, Hassan Z, Amran M, Hassal M, Mooi LY, Mohamed. 2000. Antimicrobial, antioxidant, antitumor promoting and cytotoxic activities of different plant part extracts of Garcina atroviridis Griff, Ex T anders. J. Ethnopharmacology, 72: 395402.

Mensor LL, Menezes FS, Leitao GG, Reis AS, Do Santos TC, Conbe CS, Leitao SG. 2001. Screening of brazilian plant extracts for antioxidant activity by the use of DPPH free radical method. Phytother. Res., 15: 127-130.

Meyer BN, Ferrigni NR, Pucnam JE, Acoben LB, Nichols DE, McLaughlin JL. 1982. Brine shrimp: a convenient general bioassay for active plant constituents. Planta Medica., 45: 31-34.

Middleton JrE. 1996. Biological properties of plant flavonoids: An overview. Int. Journal Pharmacology, 34: 344-348.

Neerghen VS, Soobraattee MA, Bahorun T, Aruoma OI. 2006. Characterization of the phenolic constituents in Mauritian endemic plants as determinants of their antioxidant activities in vitro. J. Plant Physiology, 163: 797 - 799.

Olagunju JA, Fagbohunka BS, Oyedapo OO, Abdul-Azeez IA. 2006. Effects of an ethanolic root extract of Plumbago zeylanica Linn. on some serum parameters of albino rat. Recent Progress in Medicinal Plants, 11(6): 267-276.

Okorie CC, Oparaocha ENT, Adewunmi CO, Iwalewa EO, Omodara SK. 2006. Antinoeicoptive, anti-inflammatory and cytotoxic activitiesof Pentaclethra macrophylla aqueous extracts in Mice. 
African J. Traditional, Complementary and Alternative Medicines, 3(1): 44-53.

Oyedapo OO. 1996. Studies on bioactivity of the extract of Plumbago zeylanica. Int. J. Pharm., 34: 365-369.

Oyedapo OO, Akinwunmi KF, Akinpelu BA. 2004. Biological effects of chronic administration of polar fraction of Plumbago zeylanica root extract on white albino rats. Nigerian J. Biochem. and Molecular Biology, 19: 47-50.

Oyedapo OO, Amos S. 1997. Further investigations into the bioactivity of root extract of Plumbago zeylanica. Phytother. Res., 11: 62-63.

Oyedapo OO, Akindele VR, Okunfolami KO. 1997. Effects of the extracts of Olax subscorpioides and Aspilia africana on bovine red blood cells. Phytother. Res., 11: $305-306$.

Pourmorad F, Hosseinimehr SJ, Shahabimajd N. 2006. Antioxidant activity, phenol and flavonoid contents of some selected Iranian medicinal Plants. African $J$. Biotech., 5(11): 1142 - 1145.

Sadique J, Al-Raobah NA, Beghaith MF, ElGindy AR. 1989. The bioactivity of certain medicinal plants on the stabilization of red blood cell membrane system. Fitoterapia LX: 525-532.

Sankaram AVB, Srinivasarao A, Sidhu GS. 1976. Chitranone- a new binaphtaquinone from Plumbago zeylanica. Phytochemistry, 15: 237 - 238 .
Simonsen HT, Nordskjold JB, Smith UW, Nyman U, Palpu P, Joshi P, Vamgbese G. 2001. In vitro Screening of Indian Medicinal Plants. J. Ethnopharmacol., 74: 195-204.

Sofowora A. 1993. Medicinal Plants and Traditional Medicine in Africa (2nd edn). Spectrum Books Limited: Ibadan, Nigeria; $150-153$.

Tilak JC, Adhikari S, Daksagayma TPA. 2004. Antioxidant properties of Plumbago zeylanica, an indian medicinal plant and its active ingredient, Plumbagin. Redox Report, 9(4): 219-227.

Trease E, Evans WC. 2002. Phenols and phenolic glycosides. In Textbook of Pharmagnosy $\left(15^{\text {th }}\right.$ edn). Elsevier Science Limited; 214-252.

Umukoro S. Asharobi RB. 2006. Evaluation of anti-inflammatory and membrane stabilizing property of aqueous extract of Momordica charantia in rats. African Journal of Biomedical Research, 9: 119124.

Van-Cangeghen P. 1972. Influence of some hydrosoluble substances with viamin $\mathrm{P}$ activity on the fragility of lysosomes in vitro. Biochemical Pharmacology, 11: 1543-1548.

Yu J, Wang L, Walzem RL, Miller EG, Pike LM, Patil BS. 2005. Antioxidant activity of citrus, limonoids, flavonoids and coumarins. Journal of Agricultural and Food Chemistry, 53: 2009-2014. 